\title{
GERINCMŰTŐ ROBOT SZIMULÁCIÓJA ARDUINO MIKROVEZÉRLŐ SEGÍTSÉGÉVEL
}

\section{SPINE ROBOT SIMULATION USING ARDUINO MICROCONTROLLER}

\author{
Kocsis Zoltán Tamás ${ }^{1}$ \\ ${ }^{1}$ Informatika Tanszék, Gépészmérnöki, Informatikai és Villamosmérnöki Kar, Széchenyi István Egyetem, \\ Magyarország \\ https://doi.org/10.47833/2021.1.CSC.003
}

Kulcsszavak:
Orvostudomány
Orvosi képalkotás
Képfeldolgozás
Robotika
Keywords:
Medical
Medical imaging
Image processing
Robotics*
Cikktörténet:
Beérkezett 2021. február 9.
Átdolgozva 2021. április 7.
Elfogadva 2021. április 12.

\section{Kulcsszavak}

Orvostudomány

Orvosi képalkotás

Képfeldolgozás

Keywords:

Medical

Medical imaging

processing

Cikktörténet:

Átdolgozva 2021. április 7.

Elfogadva 2021. április 12 .

\begin{abstract}
Összefoglalás
Az orvosi robotika egyre nagyobb szerepet játszik az orvostudományban a 21. században. Léteznek már általános orvosi robotok, amelynek egyik hátránya, hogy túlságosan nagy helyet igényelnek a mütőben. A cikkben bemutatása kerül egy kifejezetten gerincmütét elvégzéséhez fejlesztett orvosi robot modellje, ami megfelelő továbbfejlesztéssel alkalmas lehet, tényleges gerincmütétek elvégzésére.
\end{abstract}

\begin{abstract}
Medical robotics is playing an increasingly important role in medicine in the 21st century. There are already existing general medical robots, one of the disadvantages of which is that they require too much space in the operating room. This article presents a model of a medical robot developed specifically for spinal surgery, which may be suitable for performing actual spinal surgeries with appropriate development.
\end{abstract}

\section{Bevezetés}

A kutatás során a gerincmütét informatikai támogathatóságát vizsgáltuk, melynek kezdetekor megfigyeltük a digitális orvosi képeket és azok feldolgozhatóságát informatikus szemszögböl [1][2] Az elvégzett képfeldolgozás után szükséges volt egy olyan „célgépet” tervezni, amely alkalmas lesz az előállított adatok feldolgozására (szükséges pozíciók felvétele), és (felügyelet mellett) a mütét eredményes elvégzésére. Így került megtervezésre és kidolgozásra egy gerincsebészeti robot modellje.

A kidolgozás elött áttekintésre került a már rendelkezésre álló orvosi robotika, mind általános mind gerincsebészeti célú alkalmazásra. Az így szerzett ismeretek alapján sikerült egy alkalmas modellt kidolgozni. Az elsődleges cél az volt, hogy a megvalósítandó robot az előzőleg feldolgozott orvosdiagnosztikai képekböl kinyert adatok segítségével dolgozzon. A cikkben bemutatjuk a robot felépítését és működési elvét

\subsection{A gerincmütéti robotikáról röviden}

Jelenleg számos cég foglalkozik robotikával az orvostudományban. Az elkövetkezendő években nagy valószínűséggel ezeket a robotizált megoldásokat használni fogják betegségek felfedezésére, valamint a bionika és rehabilitáció során is [3]. Az általános orvosi robotikától most

\footnotetext{
* Kapcsolattartó szerző. Tel.: +36 (96) 613-652

E-mail cím: kocsis.zoltan@ga.sze.hu
} 
eltekintünk, mivel a kutatás a gerincmütét támogatására irányul, ezért csak a kifejezetten gerincmütéti robotikával foglalkozó céget ismertetnénk.

\subsubsection{Mazor robotics}

A Mazor Robotics egy izraeli orvostechnikai eszközöket gyártó cég. Ahogy a nevében is benne van robotizált gerincsebészeti műtétekhez gyárt eszközöket.[4] A termékeiket használó orvosok ortopédiai vagy gerincsebészeti mütétekre szakosodtak. A cég egy kiemelt termékkel rendelkezik, ami a Renaissance nevet viseli. Története 1990-es években Hafiában az izraeli technológiai intézet robot laboratóriumában sebészi robotok kutatásával kezdődött, melyet Moshe Shoham professzor és Eli Zehavi alapította 2001-ben. Első jelentős terméküket SpineAssist-nak nevezték melyet 2004ben hagyott jóvá az FDA (Food and Drug Administration) (1.ábra).

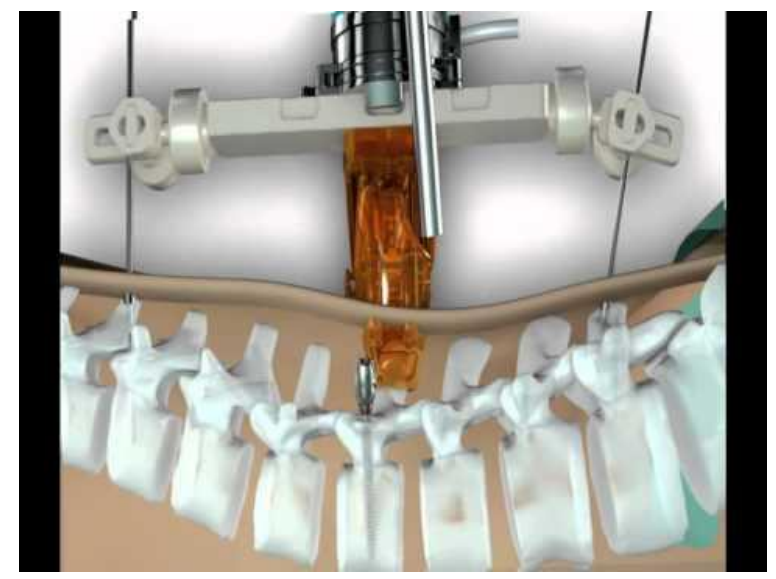

1. ábra SpineAssist [forrás:Internet 2020]

A SpineAssist rendszer egy miniatür eszközböl áll, amelyet a beteg gerincére rögzítve helyeznek el. Az eszköz kapcsolódik egy mütéti tervező szoftvert futtató munkaállomáshoz. A szoftver lehetővé teszi a mütétet végző sebészek számára, hogy CT képekből alkotott háromdimenziós képen előzetesen megtervezzék a mütétet. Tervezés előtt egy virtuális katalógusból ki lehet választani felhasználandó implantátumot, majd ezt a szoftver segítségével el lehet helyezni mindhárom síkhoz viszonyítva. A mütét eredménye így virtuálisan megtekinthető. $A$ CT felvételek több szeletböl tevődnek össze, de a szoftver egy speciális tulajdonsága révén az előzetesen elhelyezett implantátum megtekinthető az külön-külön az egyes szeleteken. A szoftver számos a mütéthez használatos mérési tartományt támogat, valamint képes szimulálni a műtétet. $A$ szimuláció segítségével az orvos képes megtekinteni a várható eredményt.

A Mazor Robotics által fejlesztett eszköz, nem képes önállóan mozogni, minden esetben egy előzetes tervezés által beállított koordinátákat kell felvennie. Ez a szoftver nem képes önállóan javaslatot adni a mütét elvégzésére. Innen jött az elképzelés, hogy egy olyan szoftver, ami az előzetes CT képek alapján képes javaslatot tenni a mütétet végző orvos számára arra, hogy hol kell a csavart elhelyezni, növelheti az elvégzett mütétek sikerességét. A SpineAssist rendszer, nem képes önállóan mozogni, csak az orvos tudja beállítani a megfelelő pozícióba, és nincs saját váza, hanem a páciens gerincére kell rögzíteni. Tovább növelhetné a mütét sikerét, ha egy olyan robotkar kerül megalósításra, ami a kinyert adatok alapján a megfelelő pozícióba képes mozogni háromdimenziós térben, majd elvégezni a mütétet ezek alapján. Egy CT felvételről tudható, hogy az pontosan hol készült a páciens testében. A CT koordináta rendszer abszolút nulla pontja az ember feje tetején helyezkedik el. A CT gépek innen kezdenek felvételeket készíteni a páciensröl.

A CT képek feldolgozása után az adatokat továbbítva a robotkarnak, képesnek kell lennie, fúráshoz szükséges bemeneti szöget felvenni, majd a felvett szögben a fúrást elvégezni. A mütét hibák minimalizálása érdekében, az orvosokkal történt előzetes egyeztetés alapján elmondható, hogy a koordinátákat tizedmilliméter pontossággal kell felvenni a mútét sikerességéhez. 


\section{A robotkar alapja}

Mielött ténylegesen kidolgozásra került a modell, szükséges volt olyan eszközöket, alkatrészeket, találni, amelyekre igazak a következők:

- Könnyen programozható,

- beszerzése nem kerül sok idöbe és megbízható,

- ha szükséges akkor könnyen lehet módosítani az eredeti felépítésén.

Az első kihívás az volt, hogy sikerüljön találni egy olyan programozható vezérlöt, ami egyrészt a megadott feladatokat tudja teljesíteni, másrészt ne legyen túl bonyolult se a kezelése se a vezérlő programozása. Egy leendő robot modelljéről van szó, tehát fontos szempont volt, hogy egy orvos számára se legyen akadály a modell irányítása. Így választottuk az Arduinot [5] ami egy olyan mikrovezérlő, amelyről elmondható, hogy rengeteg feladatra használnak, valamint a támogatottsága is széleskörü. Nagyon sok féle kezdőkészlet áll rendelkezésre a piacon ezért választás előtt fel kellett mérni, az egyes típusok milyen szolgáltatást nyújtanak, amelyek alkalmasak egy robotkar modelljének megvalósítására, ezen felül kérdés volt az, hány darab kimeneti, illetve bemeneti port áll rendelkezésre, amelyek elegendőek egy robotkar modell irányításához

\subsection{A felhasznált eszközök}

Ebben a fejezetben röviden bemutatásra kerülnek azok az eszközök melyek segítségével megvalósításra került a modell

\subsubsection{Arduino Mega2560}

A széles körü mikrovezérlő kínálatból az Arduino Mega2560 [6] típusra esett a választás. Ezt a vezérlőt olyan projektekhez készítették:

- amelyek több I/O portot, átmeneti memóriát igényelnek.

- 54 digitális I/O csatlakozóval, és 16 analóg bemenettel

- és olyan nagy átmeneti tárolóval rendelkezik, ami alkalmas lehet 3D nyomtatókhoz és robotikai eszközökhöz.

Fontos tényező volt az eszköz kiválasztásban, hogy ezt a vezérlőt számítógépre csatlakoztatva is lehet irányítani. A vezérlő az 2. ábrán látható [7]

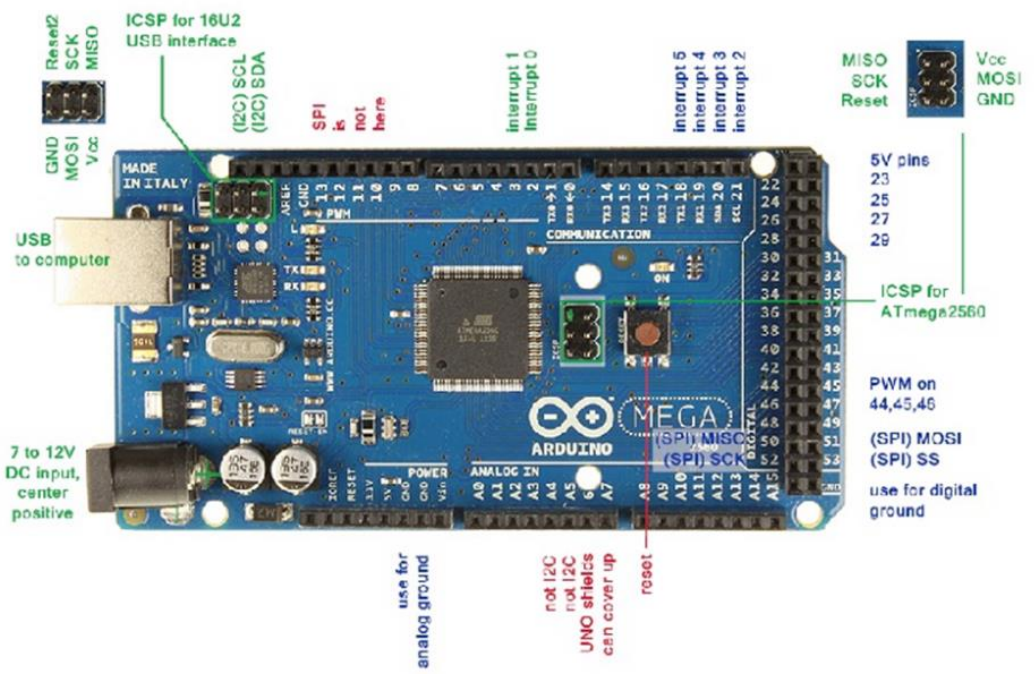

2. ábra. Arduino mega 2560 pin diagram

\subsubsection{A robotot mozgató szervomotorok}

A robotkarnak ahhoz, hogy a mütétet eltudja végezni szükséges olyan szögben mozogni ahogy azt a mütendő csigolyából kinyert mütéti adatok megkövetelik. A mozgás megvalósítására leginkább alkalmas eszköz a megfelelö követelményeket kielégítő szervomotor. Ezekből is nagyon sok féle létezik a piacon így erre a célra is át kellet tekinteni a kapható motorok specifikációját. $A$ 
megbízhatóságon, és a pontoságon túl fontos tényező, a mozgatáshoz szükséges erő leadása. Erre a feladatra az MG995-ös és MG996-os szervomotorok kerültek kiválasztásra.

$A z$ 1. táblázaton látható a motorok specifikációja.[8][9]:

1. Táblázat Az MG995 és MG996 típusú szervomotorok technikai paraméterei

\begin{tabular}{|l|l|l|l|}
\hline \multicolumn{2}{|c|}{$M G 995$} & \multicolumn{2}{c|}{ MG996 } \\
\hline $\begin{array}{l}\text { Müködési } \\
\text { sebesség: }\end{array}$ & $\begin{array}{l}4.8 \mathrm{~V}: 0.20 \mathrm{mp} / 60 \\
6,0 \mathrm{~V} 0,16 \mathrm{mp} / 60\end{array}$ & $\begin{array}{l}\text { Müködési } \\
\text { sebesség: }\end{array}$ & $\begin{array}{l}4.8 \mathrm{~V}: 0.19 \mathrm{mp} / 60 \\
6,0 \mathrm{~V} 0,15 \mathrm{mp} / 60\end{array}$ \\
\hline Nyomaték: & $10 \mathrm{~kg} / \mathrm{cm} 4.8 \mathrm{~V}$ esetén & Nyomaték: & $\begin{array}{l}10 \mathrm{~kg} / \mathrm{cm} 4.8 \mathrm{~V} \text { esetén } \\
12 \mathrm{~kg} / \mathrm{cm} \text { 6V esetén }\end{array}$ \\
\hline $\begin{array}{l}\text { Múködési } \\
\text { feszültség: }\end{array}$ & $4,8 \mathrm{~V}-7,2 \mathrm{~V}$ & $\begin{array}{l}\text { Müködési } \\
\text { feszültség: }\end{array}$ & $4,8 \mathrm{~V}-7,2 \mathrm{~V}$ esetén \\
\hline Fogaskerék: & fém & Fogaskerék: & fém \\
\hline & & Csapágyazás: & dupla soros \\
\hline
\end{tabular}

Ezeket a szervomotorokat széles körben használják modellezők kiváló tulajdonságaik miatt. Legjobb tulajdonságuk, hogy digitálisan vezérelhetőek, illetve a mozgási tartományuk 120 fokot képes lefedni, ami egy műtét elvégzésének szimulálásához elegendőnek bizonyult. A kiválasztott vezérlő és motorok után a robotkar szerkezetét kellett megvalósítani, megtervezni.

\section{A robotkar felépítése}

A robotkar elsödleges célja, megfelelni olyan követelményeknek, melyeket egy gerincsebészeti mütét igényel. Ezért figyelembe kellett venni, milyen irányban és mekkora szögben kell mozogni a kívánt mütéti pozíció eléréséhez. Számos robotkar szabadon felhasználható terve található az erre szakosodott fórumokon [10], amelyeket a kiválasztott szervóhoz terveztek. A robotkar tényleges tervének elkészülését olyan kutatómunka előzte meg amelyek során felmérésre került az, hogy a szabadon felhasználható robotkarok milyen irányban tudnak mozogni, valamint a mütét elvégzéséhez kívánt szöget fel tudják-e venni.

A robotkart alkotó elemet 3D nyomtatással kerültek megvalósításra, felépítése a 2 . ábrán látható

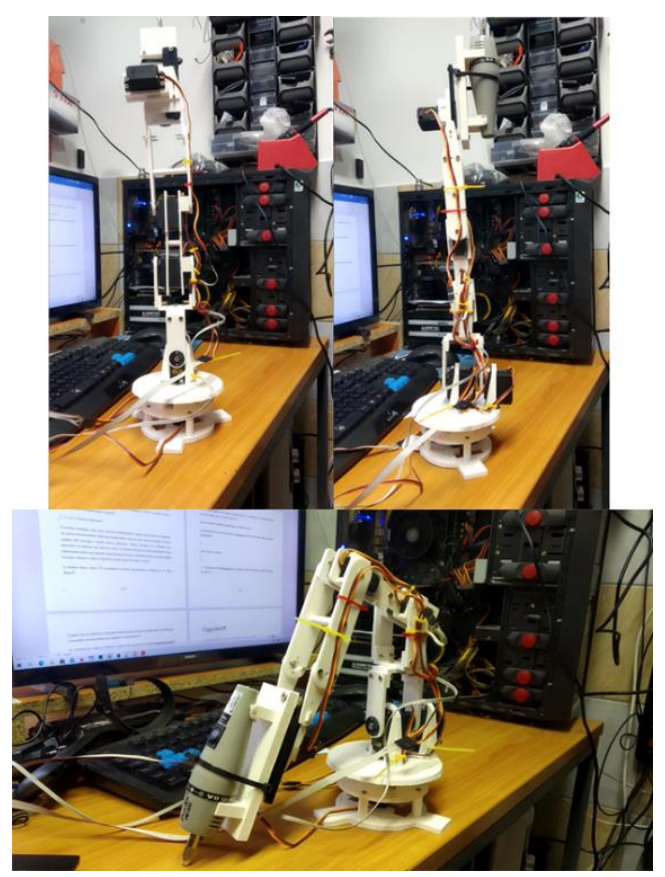

3. Ábra A robotkar modellje 
Az elkészült robotkar jelen állapotában egy olyan modell, ami a kutatás eredményességet hivatott igazolni. Az elkészült modell alkalmas lehet egy tényleges céleszköz megvalósításának alapjára. A robotkar jelenleg a következő alkatrészeket tartalmazza:

- MG995 és MG996 szervomotorok.

- A fúrófej egy 12 V-ról üzemelő panelfúró, amit egy relé segítségével lehet kapcsolni.

- A kar 3D nyomtatott alkatrészekböl épül fel.

- A vezérlést egy Arduino Mega szolgáltatja PC segítségével.

A modell vázát szolgáló alkatrészek részben saját tervezés részben szabadon felhasználható alkatrészekböl [11][12][13] állnak. A választás alapja az volt, hogy könnyen kivitelezhető legyen. Továbbá szem előtt kellett tartani a mozgással szemben elvárt követelményeket, valamint azt, hogy minél kevesebb helyet foglaljon a mütöben. Az egyik elterjedtebb mütéti robot (Da Vinci [14]) egyik hátránya a mérete, mivel túlságosan nagy helyet vesz el a mütéti térből. Ebből kifolyólag, az egyik fő szempont a robotkar méretének minimalizálása volt. A modell mérete jelenlegi állapotába körülbelül akkora, mint egy emberi kéz, valamint mozgása és felépítése is az emberi kézhez hasonló. A 2. ábrán alulról felfelé haladva láthatóak a robotkar részei:

- Az alsó talprész megfeleltethető az emberi vállnak, melyben egy szervomotor segíti a körkörös mozgást. A motor nem tud egy teljes kört mozogni csak 180 fok mozgásra képes.

- A robotkar súlyának mozgatása miatt az emberi könyök két szervomotorral helyettesítve került megvalósítása, szintén 0-180 fokban képes mozogni.

- A dupla motor feletti részben egy 90 fokkal elforgatott szervo tartó rész helyezkedik el. $A z$ elforgatásra a helyes műtéti pozíció megfelelő felvétele miatt volt szükség

- Az elöbb leírt alkatrészen egy további szervo helyezkedik el, jelenleg a működésében nincs szerepe. Amennyiben a további fejlesztés úgy határozza meg akkor felhasználásával növelhető a mütéti pontosság. Jelenleg fix 90 fokot vesz fel. Ez az alkatrész felfogható az emberi csuklónak.

- A robotkar elején a fúró helyezkedik el egy mozgatható állványon. Jelenleg a szemléltetés kedvéért egy panelfúró berendezést alkalmaztunk. A mozgatást szintén egy szervomotor hivatott elvégezni, melyre egy fogaskerék került rögzítésre, ami egy fogasléchez kapcsolódik, erre lett rögzítve a fúró tartó állvány. A mozgás egy oda-vissza irányú vízszintes mozgás, melynek segítségével kivitelezhető a fúrás

A robotkar tervezése, és kivitelezése után egy olyan szoftvert kellett megvalósítani, amely képes volt az orvosdiagnosztikai képekből kinyert adatokat továbbítani a robotkar felé, valamint képes a mütétet szimulálni.

\section{A vezérlő szoftver}

Az Arduinon lévő vezérlőprogram úgy lett beállítva, hogy a szervok egy alap szöget vesznek fel úgy, hogy a robotkar függőleges nyugalmi helyzetben helyezkedjen el. Ezt a nyugalmi helyzetet később változtatni lehet. Ahhoz, hogy ebből a helyzetből kimozduljon a kar és felvegye a mütét elvégzéséhez szükséges pozíciót szükséges volt összekötni a vezérlőt a számítógéppel. Az összeköttetést az Arduino board USB portja valósítja meg, ami két feladatot képes ellátni. Egyrészt ezen keresztül lehet feltölteni a kívánt programot a vezérlöbe, másrészt ugyanez a port képes megvalósítani a kapcsolatot az Arduino és a számítógép között. A kapcsolat megvalósításához a fejlesztök által készített könyvtárat használtuk. A könyvtár egy virtuális COM portot hoz létre a vezérlő és a számítógép között, amire küldött utasításokat a vezérlő feldolgozni képes. A parancs küldése előtt azonban kapcsolatot kell létesíteni a vezérlő és a PC között.

A PC-n futó szoftver Visual Studio C\# nyelven került megírásra. Ebben a programozási nyelvben a kommunikációs portot a System.IO.Ports névtéren belül a SerialPort osztállyal lehet elérni. A SerialPort megfelelő metódusával kérdezhetőek le a számítógéphez csatlakoztatott kommunikációs portok, valamint létrehozható a kapcsolat melynek eredményeképp a szoftverünk már képes parancsot küldeni a kiválasztott portra. A kommunikáció során a $\mathrm{PC}$ parancsként elküldi a beállítandó szöget és a megfelelő szervomotor azonosítóját. A parancs egy sima string-ként kerül átküldésre, majd a vezérlőn futó program az elfogott parancsot értelmezi és kiadja az utasításokat a megfelelő motorra. Miután megvalósításra került az összeköttetést biztosító szoftver, szükség volt egy olyan szoftver létrehozására is, amely kapcsolatot létesít az orvosi szoftver és az Arduino között. 
A megvalósítandó szoftver tulajdonképpen egy interfészként funkcionál. A megvalósítás előtt az egyik szempont az volt, hogy a meglévő mütéti adatokat ki lehessen nyerni a már kész rendszerből, a másik pedig azt, hogy az Arduinot könnyen lehessen vezérelni és ne igényeljen különösebb szaktudást. Igaz, hogy az adatokat az interfész a már feldolgozott képekböl nyeri ki, ennek ellenére lehetőség van egyéni adatok megadására is. Erre a teszteléshez volt szükség, ezt a funkciót bármikor ki lehet kapcsolni. A robotkar vezérlő müködését legjobban egy a megvalósított szoftverből készített képernyőképek szemléltetik.

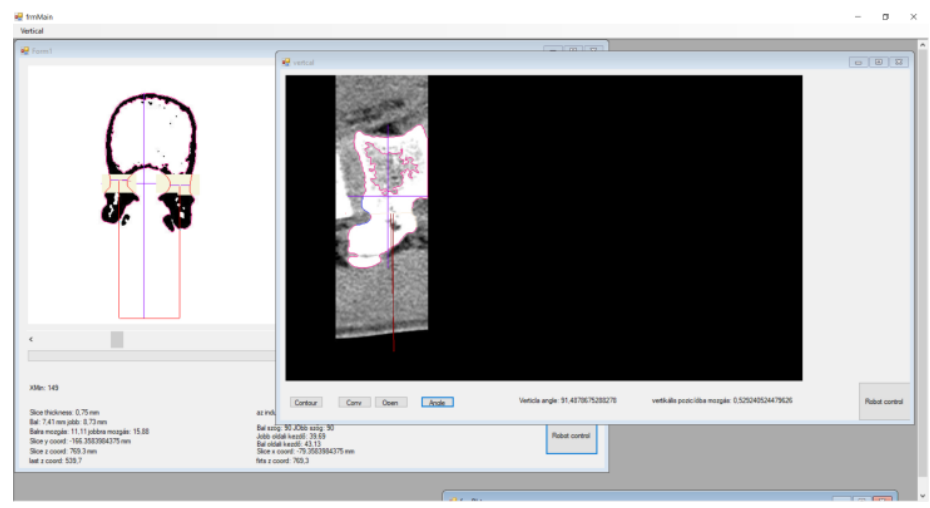

4. Ábra A mütéti robot koordinátáinak elökészítése.

$\mathrm{Az}$ 3. ábra mutatja a szoftver azon állapotát amikor a kétdimenziós koordináták után a harmadik dimenzió koordinátáit is sikerült kinyerni. Összesítve ezek a koordináták a következők:

- A csigolya jobb, illetve bal oldali fúráshoz felveendő szögek.

- A fúráshoz két dimenzióban hány millimétert szükséges mozogni jobb, illetve bal irányban.

- A csigolya metszéspontja a fúró irányát figyelembe véve.

- A harmadik dimenzió szöge.

- A harmadik dimenzió szögének felvételéhez hány millimétert kell mozogni a fúrófejnek.

A modell jelenlegi állapotában mozogni nem képes, a harmadik dimenziónak csak a szögét képes felvenni, illetve fúrni. Az így kinyert koordinátákat már továbbítani lehet a robotkar számára. A továbbításhoz egy újabb modult kellett megvalósítani, amely a 4. ábrán látható.

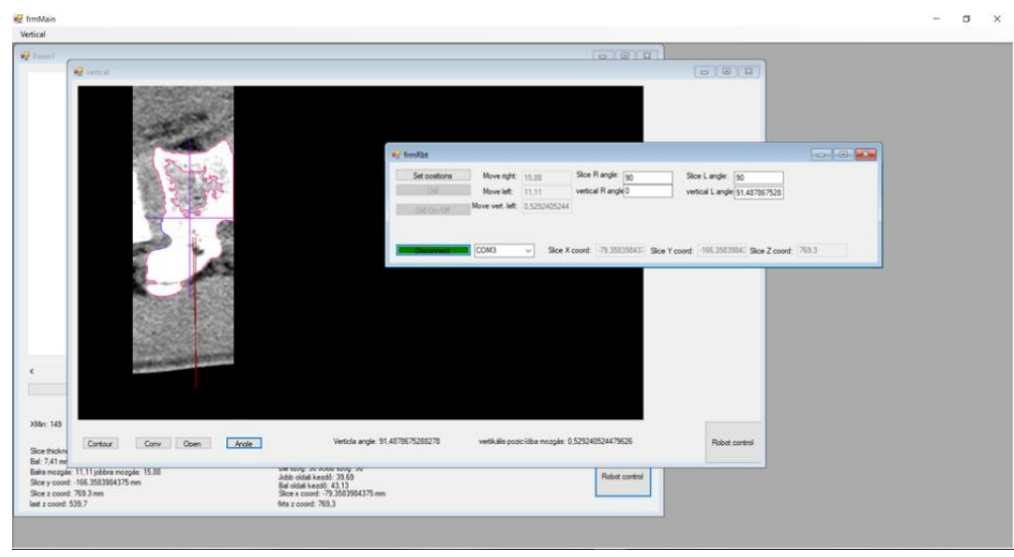

\section{5. Ábra A robotkar vezérlő szoftvere mütétre készen}

A robotkar vezérléséért felelös modul képes ellátni a következő feladatokat:

- Összegyüjti egy felületen a mütét elvégzéséhez szükséges koordinátákat.

- Képes kapcsolódni a megfelelő Arduino vezérlőhöz.

- Az összegyűjtött adatok alapján képes beállítani a robotkart a mütéthez megfelelő szögekbe.

- Képes a fúrást elvégezni.

- Képes a modellbe épített fúrót ki, illetve bekapcsolni.

Orvosokkal egyeztetve azonban arra a következtetése jutottunk, lehetöséget kell adni az orvos számára, hogy ha szükséges akkor bele tudjon nyúlni a kapott mütéti koordinátákba. Ha úgy ítéli 
meg a meghatározott mütéti pontokról, hogy azok valamilyen szempontból nem felelnek meg az elvárásoknak, akkor az orvos felülbírálhassa ezt. Jelenlegi állapotában a robotot vezérlő szoftver az előzőleg kinyert koordinátákat továbbítja a robot részére, amelyek matematikailag optimálisak, azonban az orvosi gyakorlat dönti el, hogy megfelelnek-e a mütét eredményes elvégzéséhez.

\subsection{Következtetések a modellröl}

Az elkészült modell jelenlegi állapotában képes felvenni a meghatározott mütéti pontokat és elvégezni a feladatát:

- Képes a vezérlő szoftver által CT felvételek útján feldolgozott koordinátákat felvenni (két és háromdimenzióban meghatározott szögek, ahova a csavart el kell helyezni).

- Egyik elönye közé sorolható, hogy nem kell előzetes mütéti tervezés, mivel a hozzá fejlesztett algoritmus, orvosi segítség nélkül képes pontos mütéti pontokat meghatározni.

Ezt az állapotot sok előző verzió előzte meg amelyek nem minden esetben kerültek bemutatásra. A kiválasztott szervomotorok közül egyetlen ereje nem bizonyult elegendőnek a kar mozgatására. Két szervmotor együttes alkalmazása már kielégítette a motorokkal szemben támasztott követelményeket. Összeségében elmondható, hogy a modell további fejlesztéssel és a kísérletek során felmerült, illetve felmerülő problémák javításával, hozzájárulhat egy olyan orvostechnikai eszköz kivitelezéséhez, amely a gerincmütétre szoruló betegek számára jó gyógyulási esélyeket adhat. Jelenlegi verzió nem képes műtétet végrehajtani, csak szimulálni az elvégzendő mütétet. A szimulációk során kapott adatok segítségével képesek leszünk egy tényleges mütéti robotot alkotni. A végső cél egy olyan orvostechnikai berendezés alkotása, ami egyrészt növeli a páciensek gyógyulási esélyeit, másrészt cél egy minden kórház által megfizethető eszköz megalkotása. Ennek elérése azonban, még számos év munkája.

\section{Köszönetnyilvánítás}

A kutatás a GINOP-2.3.4-15-2016-00003 - Felsőoktatási és Ipari Együttmüködési Központ támogatásával készült

\section{Irodalomjegyzék}

[1] Kocsis, Zoltán Tamás Számítógéppel támogatott képfeldolgozás gerincsebészeti alkalmazása In: Csiszár, Beáta; Bódog, Ferenc; Mező, Emerencia; Závodi, Bence (szerk.) VIII. INTERDISZCIPLINÁRIS DOKTORANDUSZ KONFERENCIA 2019 - TANULMÁNYKÖTET = 8th INTERDISCIPLINARY DOCTORAL CONFERENCE 2019 CONFERENCE BOOK Pécs, Magyarország : Pécsi Tudományegyetem Doktorandusz Önkormányzat, (2019) pp. 137-150. ISBN: 9789634293729

[2] Kocsis, Zoltán Tamás ; Kovács, János A Novel Image Processing Algorithm for Determining the Optimal Base Point of the Screw for Spinal Surgery, Journal of Electrical Engineering, Electronics, Control and Computer Science Volume 7 : Issue 24 pp. 7-12.

[3] Babbage Science and technology (18 January 2012). "Surgical robots: The kindness of strangers" . The Economist. Retrieved 21 February 2013. https://www.economist.com/babbage/2012/01/18/the-kindness-of-strangers [letöltés dátuma:2020.01.29]

[4] Spine Robotics - Mazor X Stealth Edition Robotic Guidance Platform https://www.medtronic.com/us-en/healthcareprofessionals/products/neurological/spine-robotics/mazorx.html [letöltés dátuma: 2020. 06. 29]

[5] Arudino- About us- https://www.arduino.cc/en/Main/AboutUs [letöltés dátuma: 2020.01.29]

[6] Arduino Mega2560 https://www.arduino.cc/en/Guide/ArduinoMega2560 [letöltés dátuma: 2020.11.19]

[7] Arduino Mega 2560 Board: Specifications, and Pin Configuration https://www.elprocus.com/arduino-mega-2560board/ [letöltés dátuma: 2020.11.19]

[8] TowerPro MG995 Servo Specifications and Reviews [letöltés dátuma: 2020.11.19] https://servodatabase.com/servo/towerpro/mg995

[9] TowerPro MG996 Servo Specifications and Reviews [letöltés dátuma: 2020. 11. 19.] https://servodatabase.com/servo/towerpro/mg996r

[10] https://www.thingiverse.com/ [letöltés dátuma: 2021. 02. 09.]

[11] servo Slider Demo 2 (MG995) https://www.thingiverse.com/thing:4309247 [letöltés dátuma: 2020.11.25]

[12] Roboticarm V1 - Construction Info https://www.thingiverse.com/thing:851345 [letöltés dátuma: 2020.11.25]

[13] Robotic Arm V2.0 https://www.thingiverse.com/thing:1215831 [letöltés dátuma: 2020.11.25]

Da Vinci surgical system https://www.davincisurgery.com/da-vinci-systems/about-da-vinci-systems [letöltés dátuma: 2021. 02. 09.] 